\title{
Quality monitoring of soybean seed tests using Statistical Process Control
}

\author{
Aline S. Alcântara ${ }^{1}$, Jéssica P. do Prado ${ }^{1}$, Rafael de G. Corrêa ${ }^{1}$, \\ Rouverson P. da Silva ${ }^{1}$, Murilo A. Voltarelli² \& Roberval D. Vieira ${ }^{1}$ \\ ${ }^{1}$ Universidade Estadual Paulista/Faculdade de Ciências Agrárias e Veterinárias. Jaboticabal, SP. E-mail: alineespagiari@hotmail.com (Corresponding \\ author) - ORCID: 0000-0001-8990-3094; prado.jessicapavao@gmail.com - ORCID: 0000-0002-2449-6747; rafadegraaf@gmail.com - ORCID: 0000- \\ 0003-3147-1190; rouverson@gmail.com - ORCID: 0000-0001-8852-2548; rdvieira@fcav.unesp.br - ORCID: 0000-0002-7157-3223 \\ ${ }^{2}$ Universidade Federal de São Carlos. São Carlos, SP. E-mail: voltarelli.ufscar@gmail.com - ORCID: 0000-0002-3774-1705
}

\section{Key words:}

Glycine max L. control charts quality indicators seed viability

\begin{abstract}
A B S T R A C T
The success of soybean cultivation depends on several factors, one which is the use of highquality seeds, which can guarantee growth of the desired plant population. The objective of this study was to monitor possible failures during the seed production process, and to determine the association between germination and tetrazolium tests through tools of Statistical Process Control (CEP). The experimental design was based on premises of the CEP, using percentage of germination, seed viability, mechanical damage, bed bug, and moisture as indicators of quality. It is possible to detect flaws in the soybean production process through control charts, as well as through germination and tetrazolium tests; results indicated that germination failures are largely caused by mechanical damage and bed bug attacks.
\end{abstract}

\section{Monitoramento da qualidade em testes de semente de soja utilizando Controle Estatístico de Processo}

\section{R E S U M O}

O sucesso da lavoura de soja depende de diversos fatores, entre eles cita-se a utilização de sementes de elevada qualidade fisiológica a fim de garantir a obtenção da população de plantas desejada na lavoura. Dessa forma, objetivou-se, por meio das ferramentas do Controle Estatístico de Processo (CEP), monitorar possíveis falhas no processo de produção das sementes e buscar relação entre os testes de germinação e tetrazólio. O delineamento experimental foi baseado nas premissas do CEP, utilizando como indicadores de qualidade a porcentagem de germinação, viabilidade das sementes, danos mecânicos, por percevejo e por umidade. Foi possível detectar falhas no processo de produção de sementes de soja por meio das cartas de controle, dos testes de germinação e tetrazólio, sendo principalmente estas causas relacionadas a danos mecânicos e ataque de percevejos. 


\section{INTRODUCTION}

The use of high-quality seeds is important for crops to reach their growth potential; seed quality can be assessed through factors such as physiological potential and germinative power (Oliveira et al., 2014). It is economically profitable to invest in high-quality, crop-level seeds, as this is expected to result in up to $10 \%$ increase in productivity (França Neto et al., 2012). With the growing competition and market demand, seed quality control should be more efficient (Azevedo et al., 2003).

Analyzing the physiological potentials of seeds is fundamental for making decisions regarding seed quality (Fessel et al., 2010); additionally, Statistical Process Control (CEP) can also guide the decision-making process.

CEP is an alternative to increase the quality level of indicators by reducing data variability and improving management of operations (Silva et al., 2013). The data analysis is done with the help of control charts, graphs that allow to identify common or special causes of the process, attributed to factors labor, machinery, materials, method, environment and measurement (Samohyl \& Alves, 2005).

Mechanical damages during harvest, moisture, and attacks of bedbugs are the intrinsic factors that control the processes of seed production. However, only few researchers have studied the practical monitoring quality of commercial seed lots. This study is based on the hypothesis that the CEP is a tool that when tied to the germination and tetrazolium tests can impart practicality to the seed production system. In this context, the objective of this study was to evaluate the quality of the soybean production process by using CEP tools, through the monitoring of possible shortcomings, as well as to search for possible relationships between the germination and tetrazolium tests.

\section{Material ANd Methods}

The experiment was conducted at the Laboratory of Seed Physiology and Technology of the Brazilian Agricultural Research Company - Embrapa Soja at Londrina, PR, located near the geographical coordinates of latitude $23^{\circ} 11^{\prime} \mathrm{S}$, longitude $51^{\circ} 10^{\prime} \mathrm{W}$, and altitude of $630 \mathrm{~m}$. Soybean seeds of four cultivars were used: BRS 1001 IPRO, BRS 1007 IPRO, BRS 1010 IPRO, and BRS 388 RR; each cultivar was represented by 11 lots. The initial water content of the seeds was determined (Table 1 ) at $105 \pm 3^{\circ} \mathrm{C}$ for $24 \mathrm{~h}$ using the greenhouse method, according to the Rules for Seed Analysis (Brasil, 2009).

The lots were divided into four replicates using the homogenizer/sample divider, and the samples were subjected to the following tests:

Germination test: This test was conducted using four subsamples of 50 seeds per replicate. The seeds were treated on rolls of paper moistened with a volume of water equivalent to 2.5 times the weight of the dried substrate. The models were incubated in cabinets with a germination chamber temperature set at a constant $25^{\circ} \mathrm{C}$. The evaluation was performed on the day after sowing, according to the Seed Analysis Standards (Brasil, 2009). Results of the normal variables were computed as a percentage of germination. Germination levels of less than $80 \%$ were considered inadequate, since $80 \%$ is the minimum value established by ABRASEM (2013) for the commercialization of soybeans in Brazil.

Tetrazolium test: This test was conducted with two subsamples of 50 seeds per lot. The samples were preconditioned on moist germination paper and incubated for $16 \mathrm{~h}$ in a germinator at $25^{\circ} \mathrm{C}$. After this period they were transferred to glass plates containing $0.075 \%$ tetrazolium salt solution $(50 \mathrm{~mL})$ and maintained for $2.5 \mathrm{~h}$ in the oven at $40^{\circ} \mathrm{C}$. After staining, the seeds were washed in running water and evaluated according to criteria described by França Neto et al. (1998).

The experimental design was based on the premises of Statistical Process Control (CEP), which uses regular and disciplined sampling for data classified as cross-sections. Through the use of control charts, it is possible to rapidly identify changes in strategic points of the process.

To evaluate the quality of seed production, X-bar R and mobile amplitude control charts were used as tools; size 4 subgroups were generated by the MINITAB $^{\circledR} 16$ computer program, which evaluates whether the process is under control. The X-bar $\mathrm{R}$ graph is used for multiple material flows, thus making it unnecessary to use multiple control charts in order to minimize problems (Ramos, 2000). Mobile amplitude graphs were used to analyze the variation between neighboring points within a process, as it can evaluate the variability within the process itself.

The 11 lots were grouped into four replicates for each evaluated cultivar. Sample characteristics of the subgroups were chosen with the purpose of clarifying important qualities of the process. Weights were assigned to shape defects in order to represent all groups and any other relevant characteristics for the process.

The quality indicators used were percentage of germination, percentage of seed viability, percentage of mechanical damage, percentage of damage caused by bedbugs, and percentage of damages by moisture. These indicators were used to prepare control charts regardless of data normality. According to Samohyl (2009), normality in the data, while desirable, is not fundamental to the application of CEP techniques.

In the charts, the process under control, also referred to as stable, demonstrates only random variations within the upper and lower control limits of both the X-bar R and the process variation (moving amplitude) charts. A process that is out of

Table 1. Initial water content of 11 soybean seed lots of cultivars BRS 388 RR, BRS 1010 IPRO, BRS 1001 IPRO, and BRS 1007 IPRO

\begin{tabular}{|c|c|c|c|c|c|c|c|c|c|c|c|}
\hline \multirow{2}{*}{ Cultivar } & \multicolumn{11}{|c|}{ Water content (\%) - Lots } \\
\hline & 1 & 2 & 3 & 4 & 5 & 6 & 7 & 8 & 9 & 10 & 11 \\
\hline BRS 388 & 10.60 & 10.22 & 10.54 & 10.35 & 10.25 & 10.40 & 10.85 & 10.37 & 10.15 & 10.10 & 10.05 \\
\hline BRS 1010 & 9.78 & 9.74 & 10.11 & 10.31 & 10.08 & 10.06 & 10.06 & 10.07 & 10.07 & 11.02 & 9.51 \\
\hline BRS 1001 & 9.69 & 9.65 & 9.43 & 9.49 & 9.68 & 9.45 & 9.34 & 9.42 & 9.11 & 9.27 & 9.75 \\
\hline BRS 1007 & 9.75 & 9.51 & 8.91 & 8.88 & 9.09 & 8.90 & 8.76 & 8.55 & 8.70 & 8.72 & 8.36 \\
\hline
\end{tabular}


control, that is, with points beyond the lower and upper control limits, demonstrates variations due to special causes, unmarked or non-random, that are extrinsic to the process; these were calculated based on the standard deviation of the variables, as demonstrated in Eqs. 1 and 2.

$$
\begin{aligned}
& \mathrm{UCL}=\overline{\mathrm{x}}+3 \sigma \\
& \mathrm{LLC}=\overline{\mathrm{x}}-3 \sigma
\end{aligned}
$$

where:

$$
\begin{aligned}
& \text { UCL - upper control limit; } \\
& \mathrm{x}
\end{aligned}
$$

The best estimator (E) for the graph of $\mathrm{R}$ is given by Eq. 3

$$
\mathrm{E}=\frac{\mathrm{MR}}{\mathrm{d}_{2}}
$$

where:

$$
\begin{array}{ll}
\mathrm{d}_{2} & \text { - tabulated value (Shewhart coefficient); and, } \\
\mathrm{MR} & \text { - moving range, mean amplitudes. }
\end{array}
$$

In this case, the standard deviation used defines a reasonably large area to avoid false positives; the moving average, as well as the control chart, was used to define control limits based on difference between two sequential measurements.

\section{Results AND Discussion}

The percentage of germination in each batch was analyzed, as shown in Figure 1. The cultivars BRS 388 RR and BRS 1010
IPRO exhibited greater numbers of lots with germination percentages above $90 \%$.

However, some lots exhibited germination percentage below the minimum standard defined by ABRASEM (2013), a value of $80 \%$ germination. According to the legislation, lots with germination below this value cannot be marketed as seeds, except directly with the producer.

Based on this information, it can be said that cultivars BRS 1001 IPRO and BRS 1007 IPRO are more suitable as seed producers; while all cultivars presented average germination values above the established limit of $80 \%$, BRS 388 RR and BRS 1010 IPRO produced 2 and 4 lots, respectively, with germination below the specific lower limit (SCI).

These results indicated that when analyzing the lots, application of statistical quality control allows for visualization of the reduction in quality of some of these lots, which would be masked if the analysis is based only on the average values obtained in the seed germination test.

According to Toledo et al. (2009), a reduction in quality generally translates to a decrease in the percentage of germination, an increase in abnormal seedlings, and a reduction in the vigor of seedlings. Dan (2010) stated that certain treatments can affect the emergence capacity of soybean seeds. However, other factors, such as seed damage, can also cause this effect.

In order to examine the causes underlying the values obtained in the tetrazolium test, control charts were generated with data obtained in the feasibility, mechanical damage, bed bug damage, and moisture damage analyses.

According to Marcos Filho et al. (2009), seed vigor is a reflection of the set of characteristics that determine its physiological potential, that is, its ability to show adequate performance when exposed to different environmental conditions.
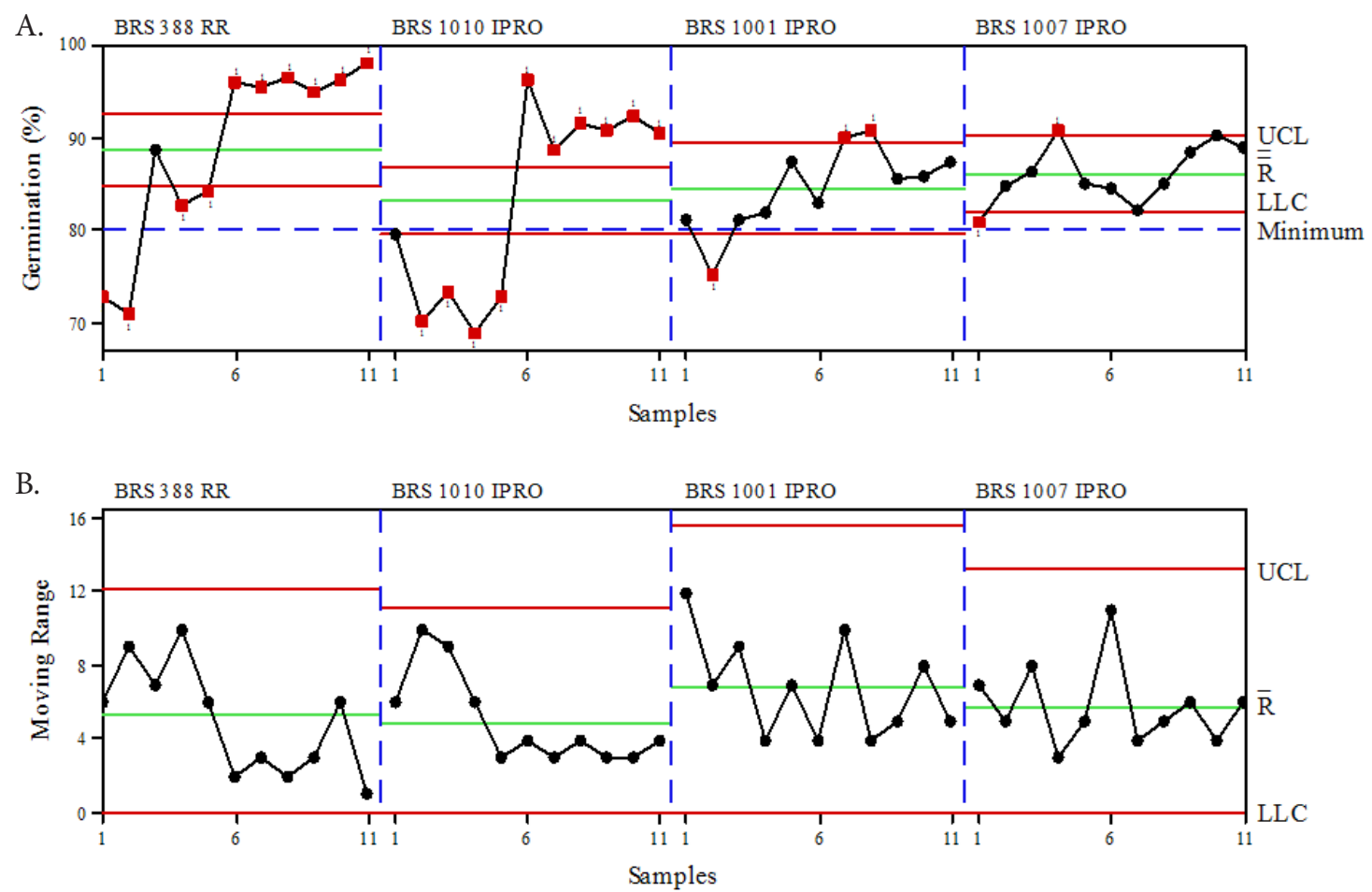

UCL - Upper control limit; LLC - Lower limit of control; $x$ - Mean; $R$ - Average of the mobile range

Figure 1. Control charts for germination (\%) of soybean seeds. Individual values (A) and mobile ranges (B) 
Regarding the percentage of germination desired, viability charts (Figure 2) show that all cultivars were stable, with the exception of cultivar BRS 1010 IPRO, which displayed five plots with viability of less than $80 \%$ (below the SCI). The cultivar BRS 388 RR also showed several points below the SCI due to low variability of the evaluated lots. However, it did not have any batch with viability lower than $80 \%$; therefore, all of its lots were considered to be suitable for commercialization. In addition, this cultivar also presented a great number of points above the LSC, which in this case can be considered a favorable characteristic that makes this cultivar stand out in relation to others.

Seed moisture in storage may have an effect on soybean viability. Smaniotto et al. (2014) concluded that initial water content influences the quality of soybean seeds during storage, as their study showed that seeds stored with the highest initial water content, $14 \%$ (b.u.), exhibited higher loss during storage.

Figure 3 shows the percentage of mechanical damage present in each batch studied. The cultivar that presented lots with lower incidence of mechanical damages was BRS 388 RR,
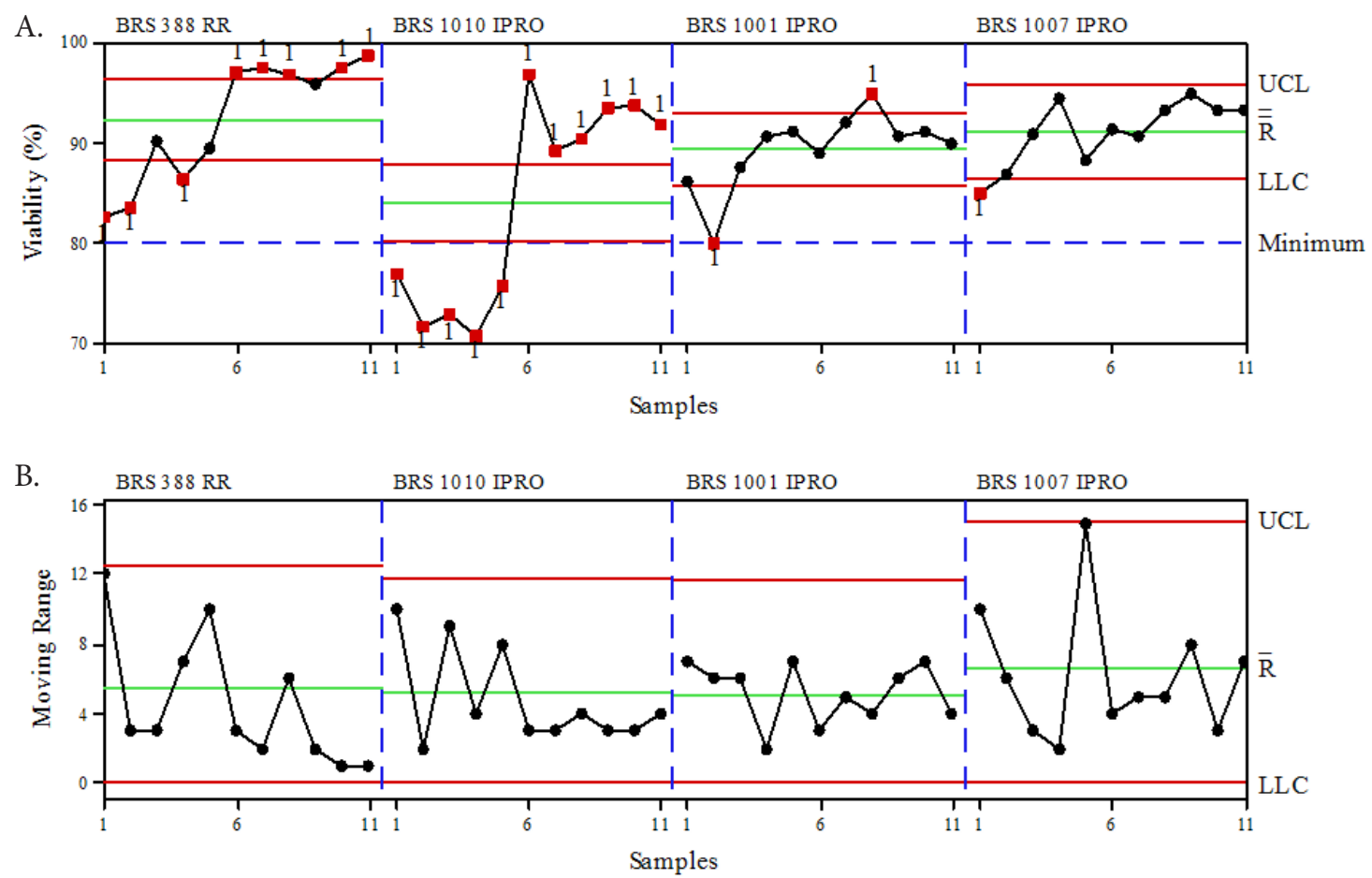

UCL - Upper control limit; LLC - Lower limit of control; $x$ - Mean; R - Average of the mobile range

Figure 2. Control charts for viability (\%) of soybean seeds. Individual values (A) and mobile range (B)
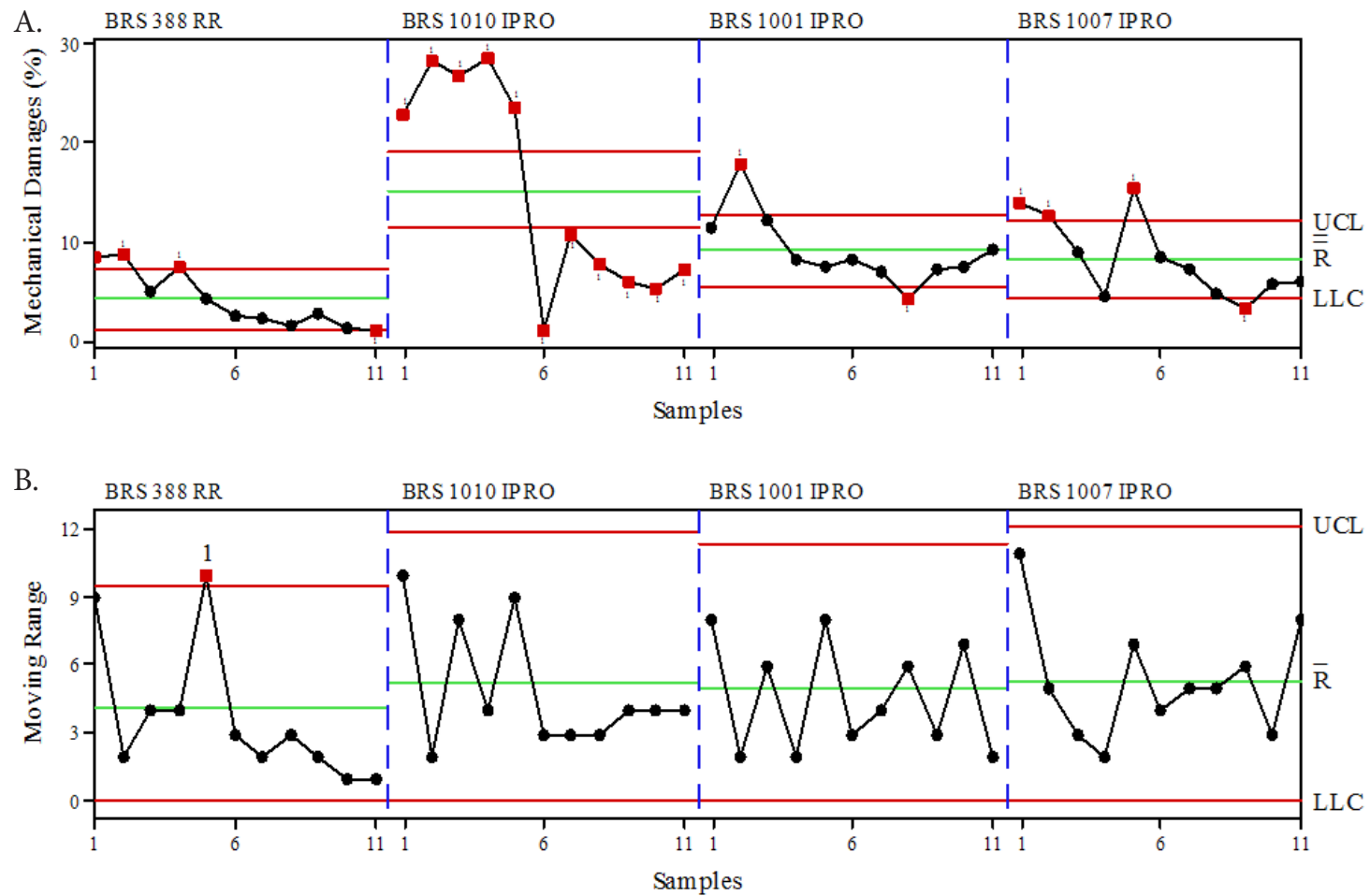

UCL - Upper control limit; LLC - Lower limit of control; $x$ - Mean; R - Average of the mobile range

Figure 3. Control charts for mechanical damage (\%) of soybean seeds. Individual values (A) and mobile range (B) 
and the cultivar with the greatest variability in the process was BRS 1007 IPRO.

The cultivar with the highest incidence of mechanical damage on lots was BRS 1010 IPRO, with values close to $30 \%$ in any given data set. BRS 1010 IPRO lots that showed high incidence of mechanical damage also demonstrated low germination. This cultivar also contained lots that were considered points out of control (below the SCI). However, these batches had lower than average mechanical damage rates, and were therefore not considered to be detrimental to the process.

Results indicated that mechanical damages are likely to be directly associated with values found in germination and viability charts, as they demonstrated an inverse relationship in control charts. Lopes et al. (2011), using the Tetrazolium test, found significant differences between the harvesting and processing stages, where manual harvesting resulted in the lowest injury rates. The high sensitivity of soybean to mechanical damage is due to the fact that the embryonic axis (radicle, hypocotyl and plumule) is located under a thin coat, which offers little protection (França Neto \& Henning, 1984).

Mechanical damage arises at several stages of the seed production process. Among the mechanized operations of the harvest, factors responsible for mechanical damage include rotation of the machine cylinder, speed of the conveyor, and grain elevator, which may cause the seeds to break. As concluded by Ferreira et al. (2007), the speed of the reel, rotation of the trellis cylinder, opening between the cylinder and the concave, and speed of displacement are among the main factors associated with losses during mechanized harvest of soybean. Furthermore, according to Chioderoli et al. (2012), the quality of the harvesting operation and the settings of the harvester are dependent on the speed of the machine.

Processing involves many steps using lifts and numerous threads and can cause seed damage. Flor et al. (2004) cited that among the causes responsible for loss of quality in soybean seeds, most mechanical damages occur during harvesting and processing operations. Surface cracks are easily detected, while internal mechanical damage requires more detailed examination for detection. Not only large and visible damages but also minor damages or micro damages, depending on their locations, can significantly reduce seed quality.

In addition to mechanized operations, it is possible that the cause of further damage lies with the cultivar, which may have low resistance to mechanical damage. Costa et al. (1996) considered this to be an important point when evaluating mechanical damages, as there are genetic differences among the various cultivars available in the market.

Damage values caused by stink bug (Figure 4) showed that cultivars BRS 388 RR and BRS 1010 IPRO exhibit unstable processes, unlike BRS 1001 IPRO and BRS 1007 IPRO. In addition, BRS 1007 IPRO showed lower attack rate and variability, which consequently lead to better seed quality.

Bed bug attacks on soybean plant are considered to be one of the most important factors that negatively impact the physiological quality of soybean seeds; thus, proper management of bed bugs should be effective in improving yield. BRS 388 RR exhibited low resistance to bed bug damage, resulting in higher attack rate, greater process variability, and reduced seed quality.

Control charts for moisture damage (Figure 5) showed that the cultivar BRS 388 RR exhibited instability. In addition, the cultivar BRS 1010 IPRO demonstrated lower variability of deterioration, and greater variability as compared with that of BRS 388 RR.

Results suggested that in the cultivar BRS $388 \mathrm{RR}$, damages by humidity resulting in values above the LSC may be associated with damage by bedbugs, since bedbug bites rupture the membrane of these seeds, allowing for entry of water,
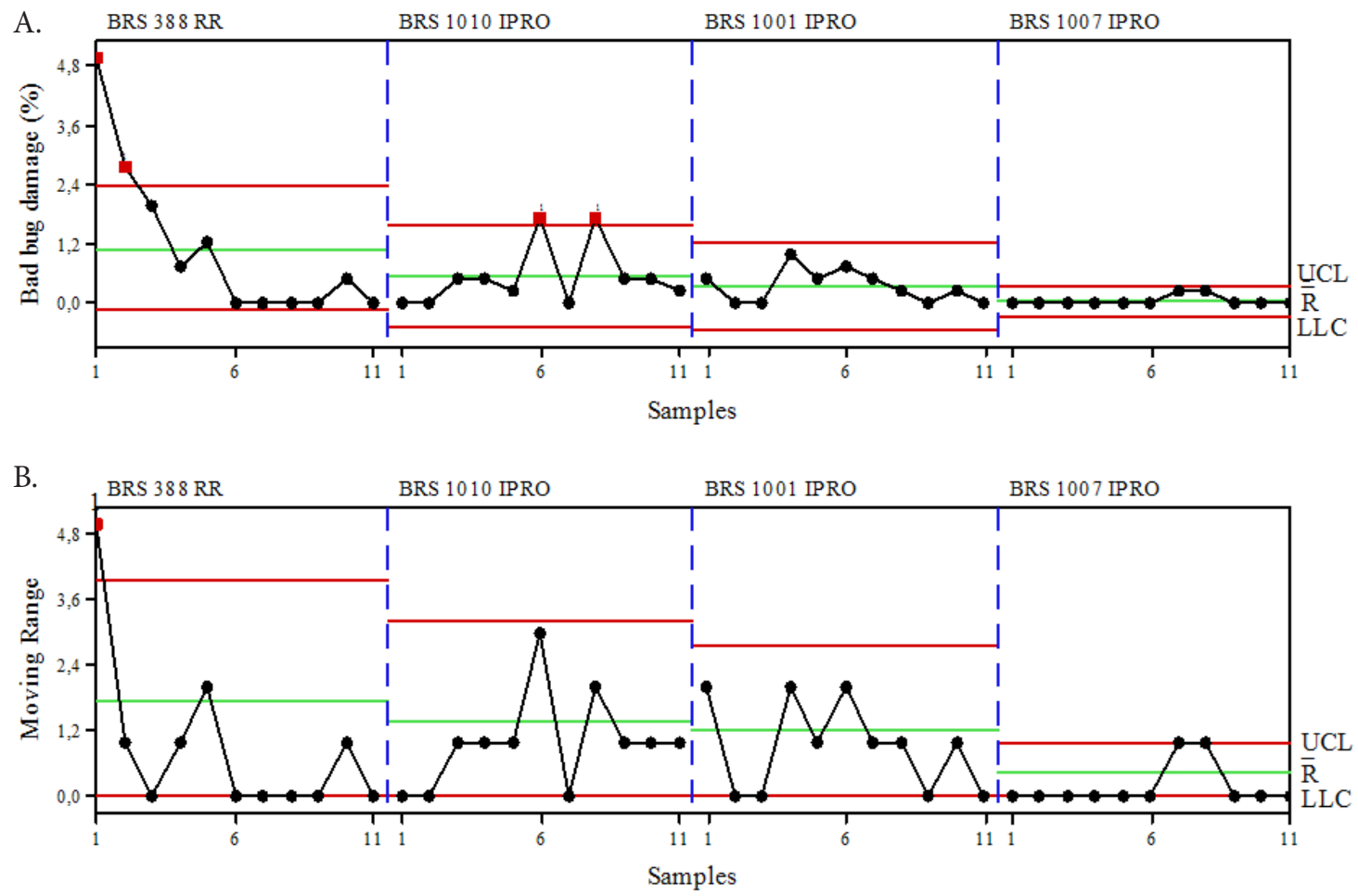

UCL - Upper control limit; LLC - Lower limit of control; $x$ - Mean; R - Average of the mobile range

Figure 4. Control charts for bed bug damages (\%) of soybean seeds. Individual values (A) and mobile range (B) 

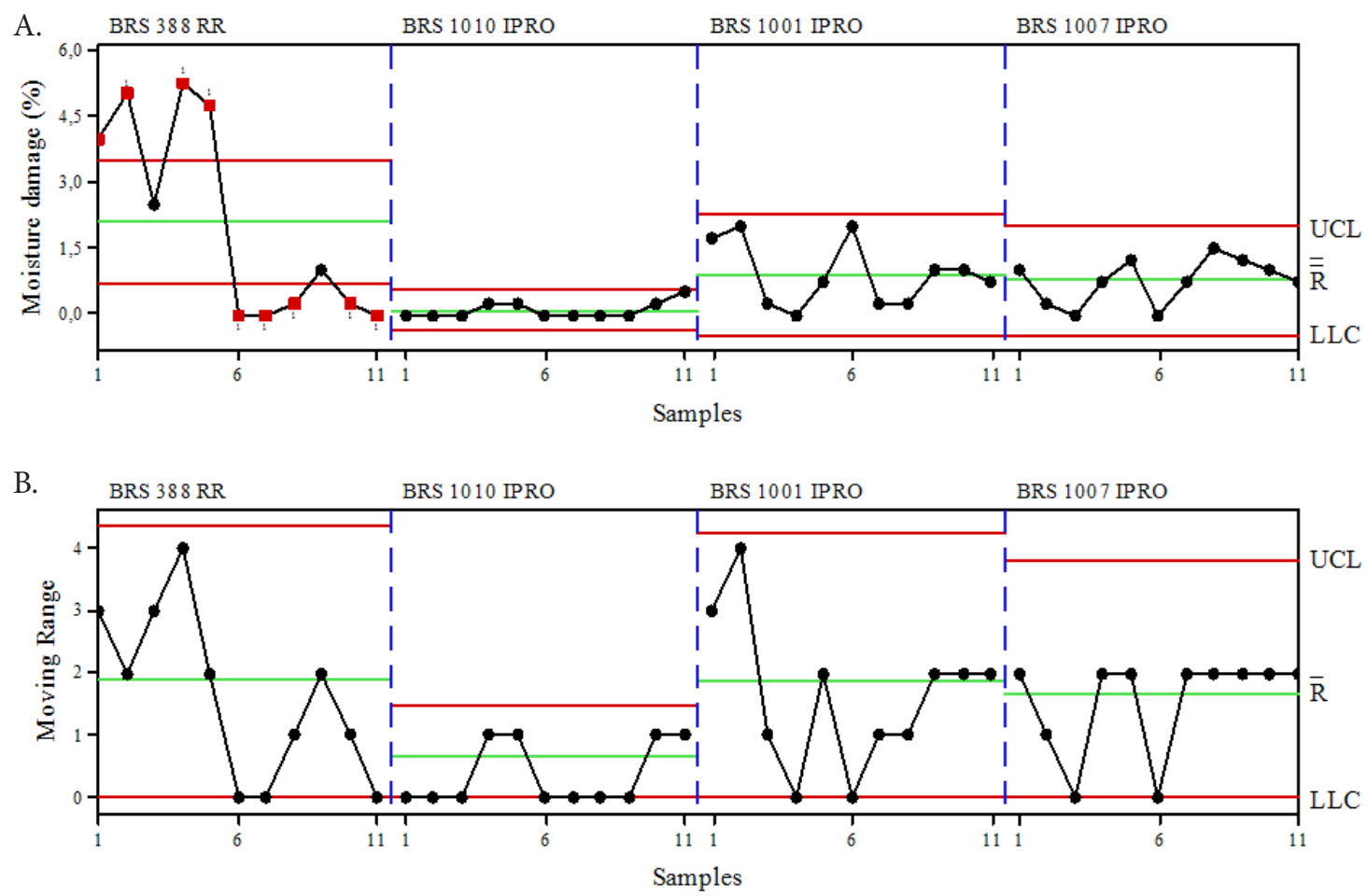

UCL - Upper control limit; LLC - Lower limit of control; $x$ - Mean; R - Average of the mobile range

Figure 5. Control charts for moisture damage (\%) of soybean seeds. Individual values (A) and mobile range (B)

which consequently leads to greater damages by humidity. However, lots found under the SCI, which were considered to be unstable as they present lower rates of damage, are, in fact, desirable for cultivation.

The variations in the relative air humidity can also cause damages to the seed, such as increasing the incidence of cracking, tegumentation, and moisture damage; the latter is responsible for a $24 \%$ reduction in seed vigor (Marcandalli et al., 2011).

In Brazil, where high temperatures and abundant rainfall occur, preference should be given to seed production in regions where the climate between the ripening and the harvesting season is mild and dry. Seeds that suffer from excessive rainfall in the period before harvesting may be damaged due to humidity, and lose its germination and vigor at high rates during storage, mainly due to the evolution of the indices of this type of damage (Costa et al. 2001, 2005). Therefore, the seed should be harvested at the appropriate time, as the delay in harvesting will result in reductions in germination and vigor.

\section{Conclusions}

1. The relationship between the Germination Test and the Tetrazolium was checked using the control charts.

2. It is possible through statistical process control to identify seed lots that do not meet the minimum quality standard. Analysis of cultivar lots are advantageous in determining cultivars that are suitable for commercialization.

\section{Literature Cited}

ABRASEM - Associação Brasileira Sementes e Mudas. Instruções Normativas No 45, de 17 de setembro de 2013. Brasília: MAPA, 2013. 16p.
Azevedo, M. R. Q. A.; Gouveia, J. P. G.; Trovão, D. M. M.; Queiroga, V. P. Influência das embalagens e condições de armazenamento no vigor de sementes de gergelim. Revista Brasileira de Engenharia Agrícola e Ambiental, v.7, p.519-524, 2003. https:// doi.org/10.1590/S1415-43662003000300019

Brasil. Ministério da Agricultura Pecuária e Abastecimento. Regras para análise de sementes. Brasília: MAPA/ACS, 2009. 395p.

Chioderoli, C. A.; Silva, R. P.; Noronha, R. H. F.; Cassia, M. T.; Santos, E. P. Perdas de grãos e distribuição de palha na colheita mecanizada de soja. Bragantia, v.71, p.112-121, 2012. https://doi. org/10.1590/S0006-87052012005000003

Costa, N. P.; Mesquita, C. M.; Maurina, A. C.; França Neto, J. B.; Krzyzonowski, F. C.; Oliveira, M. C. N.; Henning, A. A. Perfil dos aspectos físicos, fisiológicos e químicos de sementes de soja produzidas em seis regiões do Brasil. Revista Brasileira de Sementes, v.27, p.1-6, 2005. https://doi.org/10.1590/S010131222005000200025

Costa, N. P.; Mesquita, C. M.; Maurina, A. C.; França Neto, J. B.; Pereira, J. E.; Bordingnon, J. R.; Krzyzanowski, F. C.; Henning, A. A. Efeito da colheita mecânica da soja nas características físicas, fisiológicas e químicas das sementes em três estados do Brasil. Revista Brasileira de Sementes, v.23, p.140-145, 2001. https://doi. org/10.17801/0101-3122/rbs.v23n1p140-145

Costa, N. P.; Oliveira, M. C. N.; Henning, A. A.; Krzyzanowski, F. C.; Mesquita, C. M.; Tavares, L. C. V. Efeito da colheita mecânica sobre a qualidade de semente de soja. Revista Brasileira de Sementes, v.18, p.232-237, 1996. https://doi.org/10.17801/0101-3122/rbs. v18n2p232-237

Dan, L. G. M. Qualidade fisiológica de sementes de soja tratadas com inseticidas sob efeito do armazenamento. Revista Brasileira de Sementes, v.32, p.131-139, 2010. https://doi.org/10.1590/S010131222010000200016 
Ferreira, I. C.; Silva, R. P.; Lopes, A.; Furlani, C. E. A. Perdas quantitativas na colheita de soja em função da velocidade de deslocamento e regulagens no sistema de trilha. Revista Engenharia na Agricultura, v.15, p.141-150, 2007.

Fessel, S. A.; Panobianco, M.; Souza, C. R.; Vieira, R. D. Teste de condutividade elétrica em sementes de soja armazenadas sob diferentes temperaturas. Bragantia, v.69, p.207-214, 2010. https:// doi.org/10.1590/S0006-87052010000100026

Flor, E. P. O.; Cicero, S. M.; França Neto, J. D. B.; Krzyzanowski, F. C. Avaliação de danos mecânicos em sementes de soja por meio da análise de imagens. Revista Brasileira de Sementes, v.26, p.68-76, 2004. https://doi.org/10.1590/S0101-31222004000100011

França Neto, J. B.; Henning, A. A. Qualidade fisiológica e sanitária de sementes de soja. Londrina: Embrapa Soja, 1984. 39p. Circular Técnica, 9

França Neto, J. B.; Krzyzanowski, F. C.; Costa, N. P. O teste de tetrazólio em sementes de soja. Londrina: Embrapa Soja, 1998 72p. Documentos, 116

França Neto, J. B.; Krzyzanowski, F. C.; Henning, A. A. Plantas de alto desempenho e a produtividade da soja. Seed News, v.16, p.8-11, 2012.

Lopes, M. M.; Prado, M. O. D.; Sader, R.; Barbosa, R. M. Efeitos dos danos mecânicos e fisiológicos na colheita e beneficiamento de sementes de soja. Bioscience Journal, v.27, p.230-238, 2011.

Marcandalli, L. H.; Lazarini, E.; Malaspina, I. C. Épocas de aplicação de dessecantes na cultura da soja: Qualidade fisiológica de sementes. Revista Brasileira de Sementes, v.33, p.241-250, 2011. https://doi. org/10.1590/S0101-31222011000200006
Marcos Filho, J.; Kikuti, A. L.; Lima, L. B. Métodos para avaliação do vigor de sementes de soja, incluindo a análise computadorizada de imagens. Revista Brasileira de Sementes, v.31, p.102-112, 2009. https://doi.org/10.1590/S0101-31222009000100012

Oliveira, S.; Ludwig, M. P. R.; Crizel, R. L.; Lemes, E. S.; Lucca Filho, O. A. Amassamento durante o manejo do cultivo: Efeito no rendimento e na qualidade de sementes de soja. Bioscience Journal, v.30, p.1059-1069, 2014.

Ramos, A. W. CEP para processos contínuos e em bateladas. 1.ed. São Paulo: Edgard Blucher, 2000. 144p.

Samohyl, R. W. Controle estatístico de qualidade. Rio de Janeiro: Elsevier, 2009. 275p.

Samohyl, R. W.; Alves, C. C. O monitoramento de processos industriais via gráficos de controle CUSUM. Revista UNIVILLE, v.10, p.72-80, 2005.

Silva, R. P.; Cassia, M. T.; Voltarelli, M. A.; Compagnon, A. M.; Furlani, C. E. A. Qualidade da colheita mecanizada de feijão em dois sistemas de preparo do solo. Revista Ciência Agronômica, v.44, p.61-69, 2013. https://doi.org/10.1590/S1806-66902013000100008

Smaniotto, T. D. S.; Resende, O.; Marcal, K. A.; Oliveira, D. E. C.; Simon, G. A. Qualidade fisiológica das sementes de soja armazenadas em diferentes condições. Revista Brasileira de Engenharia Agrícola e Ambiental, v.18, p.446-453, 2014. https:// doi.org/10.1590/S1415-43662014000400013

Toledo, M. Z.; Fonseca, N. R.; César, M. L.; Soratto, R. P.; Cavariani, C.; Crusciol, C. A. C. Qualidade fisiológica e armazenamento de sementes de feijão em função da aplicação tardia de nitrogênio em cobertura. Pesquisa Agropecuária Tropical, v.39, p.124-133, 2009. 